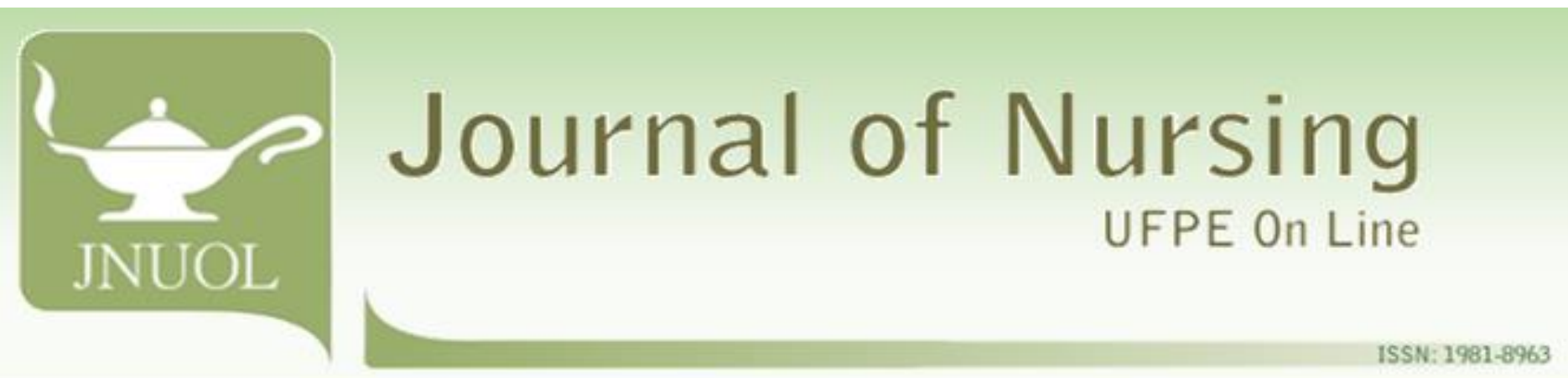

\title{
INTEGRATIVE LITERATURE REVIEW ARTICLE
}

\section{ACTIONS OF NURSES DIRECTED AT OBESE TEENS IN PRIMARY CARE AÇÕES DE ENFERMEIROS DIRECIONADAS A ADOLESCENTES OBESOS NA ATENÇÃO PRIMÁRIA ACCIONES DE ENFERMEROS PARA ADOLESCENTES OBESOS EN ATENCIÓN PRIMARIA}

Maria Cristina Pinto de Jesus ${ }^{1}$, Vanessa Augusta Souza Braga ${ }^{2}$, Ana Paula da Silva Pinheiro ${ }^{3}$, Renata Evangelista Tavares Machado ${ }^{4}$, Marcelo Henrique da Silva ${ }^{5}$, Sueli Maria dos Reis Santos ${ }^{6}$, Miriam Aparecida Barbosa Merighi ${ }^{7}$

\section{ABSTRACT}

Objective: to identify the scientific production on nurses' actions directed to obese adolescents in Primary Health Care. Method: this is a descriptive bibliographic study, integrative literature review, from the search for indexed publications in the databases between 2010 and 2018: CINAHL, LILACS, MEDLINE, SCOPUS and Web of Science and SciELO Virtual Library. The method of reading and evaluation by level of evidence was used to perform the descriptive analysis of the data, which were presented in a synoptic table. Results: 13 articles were selected. It was evidenced that the actions of nurses directed to obese adolescents in Primary Health Care aimed at stimulating healthy eating, physical activity practice and improving self-esteem for weight reduction through health counseling, use of technologies, involvement family and intersectoral articulation, including the school. Conclusion: there is a need for the development of longitudinal, intersectoral and broad actions. It is important to invest more in the training of nurses in order to perform interventions in the primary care, aimed at obese adolescents, with reference to comprehensive care. Descriptors: Adolescent; Adolescent Health; Obesity; Nursing, Practical; Primary Health Care; Review.

\section{RESUMO}

Objetivo: identificar a produção científica sobre ações do enfermeiro dirigidas a adolescentes obesos na Atenção Primária à Saúde. Método: trata-se de um estudo bibliográfico, descritivo, tipo revisão integrativa da literatura, a partir da busca de publicações indexadas nas bases de dados entre 2010 e 2018: CINAHL, LILACS, MEDLINE, SCOPUS e Web of Science e Biblioteca Virtual SciELO. Recorreu-se ao método de leitura e avaliação por nível de evidência para realizar a análise descritiva dos dados, que se apresentaram em quadro sinóptico. Resultados: selecionaram-se 13 artigos. Evidenciou-se que as ações do enfermeiro direcionadas a adolescentes obesos na Atenção Primária à Saúde visaram ao estímulo à alimentação saudável, prática de atividade física e melhora da autoestima para a redução do peso, por meio de aconselhamento em saúde, uso de tecnologias, envolvimento da família e articulação intersetorial, incluindo a escola. Conclusão: aponta-se a necessidade de desenvolvimento de ações longitudinais, intersetoriais e amplas. Torna-se importante maior investimento no treinamento de enfermeiros com vistas à realização de intervenções, no âmbito da atenção primária, voltadas para adolescentes obesos, tendo por referência o cuidado integral. Descritores: Adolescente; Saúde do Adolescente; Obesidade; Enfermagem Prática; Atenção Primária à Saúde; Revisão.

\section{RESUMEN}

Objetivo: identificar la producción científica sobre las acciones del enfermero dirigidas a adolescentes obesos en Atención Primaria de Salud. Método: estudio bibliográfico, descriptivo, tipo revisión bibliográfica integradora de la literatura, basado en la búsqueda de publicaciones indexadas en las bases de datos entre 2010 y 2018: CINAHL, LILACS, MEDLINE, SCOPUS y Web of Science y SciELO Virtual Library. El método de lectura y evaluación por nivel de evidencia se utilizó para realizar el análisis descriptivo de los datos, que se presentaron en una tabla sinóptica. Resultados: se seleccionaron 13 artículos. Se evidenció que las acciones de los enfermeros dirigidas a adolescentes obesos en Atención Primaria de Salud tenían como objetivo estimular la alimentación saludable, la práctica de actividad física y la mejora de la autoestima para la reducción de peso a través de asesoramiento en salud, el uso de tecnologías, participación de la familia y articulación intersectorial, incluida la escuela. Conclusión: existe la necesidad de desarrollar acciones longitudinales, intersectoriales y amplias. Es importante invertir más en la capacitación de enfermeros para realizar intervenciones en la atención primaria, dirigidas a adolescentes obesos, con referencia a la atención integral. Descriptores: Adolescente; Salud del Adolescente; Obesidad; Enfermería Práctica; Atención Primaria de Salud; Revisión.

1,3,5,6Federal University of Juiz de Fora/UFJF. Juiz de Fora (MG), Brasil. Bhttps://orcid.org/0000-0002-8854-690X (Dhttps://orcid.org/0000-00031417-512X Chttps://orcid.org/0000-0003-0940-0599 - Ohttps://orcid.org/0000-0002-6250-5050 2,4,7University of São Paulo/USP. Sao Paulo (SP), Brazil. 1 https://orcid.org/0000-0001-6714-9318 1 https://orcid.org/0000-0001-9004-3941 1 https://orcid.org/0000-0002-9705-2557

Article extracted from the Course Conclusion Work $\ll$ The nurse and the actions aimed at the adolescent public in Primary Health Care: integrative review >>. Juiz de Fora Federal University. 2018.

How to cite this article

Jesus MCP, Braga VAS, Pinheiro APS, Machado RET, Silva MH, Santos SMR, et al. et al. Actions of nurses directed at obese teens in primary care. J Nurs UFPE on line. 2019;13:e240871 DOI: https://doi.org/10.5205/1981$\underline{8963.2019 .240871}$ 


\section{INTRODUCTION}

It is identified that the prevalence of overweight and obesity is increasing considerably in urban areas of low and middle income countries, affecting mainly young and adults, previously more prominent phenomenon in developed countries. It is noteworthy that World Health Organization (WHO) estimates show that among children and adolescents aged five to 19 years, the prevalence of overweight and obesity rose dramatically from $4 \%$ in 1975 to just over $18 \%$, in $2016 .^{1}$

From the assessment of the Body Mass Index (BMI), $8.4 \%$ of Brazilian adolescents between 12 and 17 years are obese and $25.5 \%$ overweight. ${ }^{2}$ It is known that obesity in adolescence It is associated with mental health problems, asthma, obstructive sleep apnea, orthopedic problems, cardiovascular and metabolic diseases such as hypertension and insulin resistance. ${ }^{3}$ It is also observed that adolescents may experience bullying due to their excessive weight.

A meta-analysis showed an association between obesity and depression in obese individuals compared to those who were only overweight. ${ }^{4}$ It is emphasized that such adolescent health problems tend to perpetuate during adulthood and impact morbidity and mortality of these people.

It is known that adolescence is a fundamental moment for obesity prevention and control interventions, since young people experience a stage characterized by a complex process of biopsychosocial growth and development, and therefore an important period to invest in efforts to protect and promote health. ${ }^{5}$

In this sense, the importance of the role of the multidisciplinary Primary Health Care (PHC) team is highlighted, in which the nurse occupies the role of coordinator of the development of actions, especially those aimed at children and adolescents. It is understood that nurses' efforts to implement practices and policies aimed at this audience can help improve health outcomes and overcome barriers faced by obese adolescents in seeking care. ${ }^{6}$

This review aims to contribute to the reflection on the interventions developed by nurses in PHC aimed at adolescents with obesity, which may subsidize the health team, especially nurses, to guide their actions based on evidence identified in the included studies.

\section{OBJECTIVE}

- To identify the scientific production on nurses' actions directed to obese adolescents in Primary Health Care.

\section{METHOD}

This is a bibliographical, descriptive study, integrative literature review type, which allows the capture, critical appreciation and synthesis of knowledge about the object investigated, allowing the apprehension of themes or problems relevant to the field of health and public policies. ${ }^{7}$

The following steps were followed for the systematization of this review: formulation of the guiding question; definition of inclusion and exclusion criteria of studies; establishment of the information to be drawn from the chosen studies; evaluation of studies included in the research; interpretation of results and synthesis of knowledge evidenced in the described articles. ${ }^{7}$

The following research question was elaborated: "What is the scientific production on nurses' actions directed to obese adolescents in Primary Health Care?". The search for publications was guided by the PICO strategy (Patient, Intervention, Context and Outcomes), ${ }^{8}$ where $\mathrm{P}=$ obese adolescents; $\mathrm{I}=$ actions of the nurse; $\mathrm{C}=$ Primary Health Care and $\mathrm{O}=$ scientific production found.

Data was collected in January and February 2019 by electronic search of scientific articles in the following databases: Scopus Info Site (SCOPUS); Latin American and Caribbean Health Sciences Literature (LILACS); Cumulative Index to Nursing and Allied Health Literature (CINAHL), Web of Science and Virtual Scientific Electronic Library Online (SciELO). The timeframe was delimited from 2010 to 2018, and was the starting point established after the publication of the document "Adolescent Job Aid", by WHO, aimed at primary level health professionals to guide interventions aimed at to teenagers. ${ }^{9}$

For the search, the descriptors "primary health care", "nurses", "adolescent" and "obesity" obtained by consulting the Descriptors in Health Sciences (DeCS) and the Medical Subject Headings (MESH) and the synonyms : "Primary health care" / "primary care" / "community care"); ("Nurses" / "nurse practitioners" / "nursing”); (“Adolescent” / “adolescent health" / “teen”) and ("obesity" / "obese"). We chose to use the English language terms and the Boolean operators AND and OR.

The following inclusion criteria were used for the composition of the sample: articles resulting from research and systematic reviews that highlighted actions performed by nurses directed to adolescents with obesity, at the PHC level, in English, Spanish and Portuguese, published between 2010 and 2018, containing the terms raised in the title, descriptors, or body of abstracts, available in their entirety and free online.

One chose to use the term adolescence, without defining a standard definition, in order to 
Jesus MCP, Braga VAS, Pinheiro APS, et al

broaden the spectrum of productions to be analyzed. Experience reports, dissertations, theses and gray literature were excluded, as well as duplicates found in more than one database.

Studies were classified into seven hierarchical levels of evidence: level 1 - systematic review or meta-analysis of multiple controlled randomized controlled trials or derived from clinical guidelines based on systematic reviews of randomized controlled trials; level 2 - evidence from at least one well-designed randomized controlled trial; level 3 - evidence from well-designed clinical trials without randomization; level 4 - evidence obtained from well-designed cohort and casecontrol studies; level 5 - evidence from systematic review of descriptive and qualitative studies; level 6 - evidence from a single descriptive or qualitative study; Level 7 - Evidence from the opinion of authorities and / or expert committee reports. $^{10}$

An instrument was developed that allowed the descriptive analysis of the main information of the publications and encompassed the title, authorship, country and year of publication,
Actions of nurses directed at obese teens in...

research design, participants, intervention, outcome and level of evidence. A synoptic framework was built from the articles that met the inclusion criteria established that covered the evaluated aspects.

The papers were screened by a pair of reviewers independently. The article was considered when at least one of the reviewers deemed it eligible. Disagreements between reviewers were resolved by consensus between the pair or by consulting a third reviewer.

\section{RESULTS}

3,460 articles were identified in the databases and a total of 3,298 were excluded because they did not meet the inclusion criteria and / or did not answer the guiding question of the research. One hundred and thirty-five articles eligible for full reading were selected and, from these, 13 articles were elected to compose the definitive study set of the review (Figure 1). 


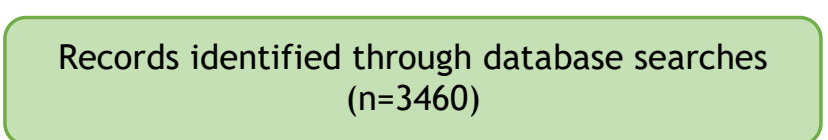

Records identified through searches in other data sources $(n=0)$

\section{을}

Records after deleting duplicate studies $(n=3433)$

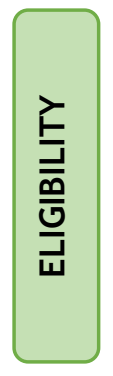

Studies selected for
full reading $(n=135)$

Complete studies evaluated for eligibility $(n=38)$

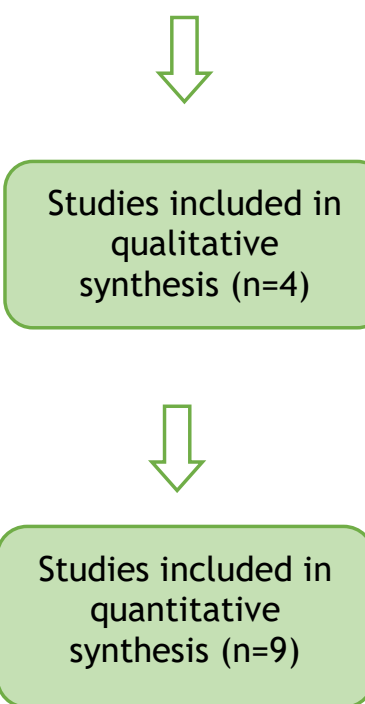

Figure 1. Flowchart of study selection, according to the Preferred Reporting Items for Systematic Reviews and MetaAnalyzes (PRISMA 2009). Sao Paulo (SP), Brazil, 2019.

A total of 13 studies that included actions of nurses directed to obese adolescents in Primary Health Care were included, of which $53.8 \%$ were classified as level of evidence 2 (Figure 2). As the country with the largest number of publications, the United States of America (USA) stood out, representing $69.2 \%$ of the selected studies. 


\begin{tabular}{|c|c|c|c|c|}
\hline $\begin{array}{l}\text { Author Year } \\
\text { Country }\end{array}$ & $\begin{array}{c}\text { Design } \\
\text { Participants }\end{array}$ & Interventions & Outcome & $\begin{array}{l}\text { Level of } \\
\text { evidence }\end{array}$ \\
\hline $\begin{array}{l}\text { Kelishadi, Malekahmadi, Hashemipour, Soghrati, } \\
\text { Soghrati, Mirmoghtadaee, et al. } 2012^{11} \\
\text { Iran }\end{array}$ & $\begin{array}{l}\text { Nonrandomized clinical } \\
\text { trial. } \\
\mathrm{n}=457 \\
\text { obese children and } \\
\text { adolescents, aged two to } \\
18 \text { years. }\end{array}$ & $\begin{array}{l}\text { A healthy lifestyle incentive program was } \\
\text { conducted to control childhood obesity and } \\
\text { associated cardiometabolic risk factors, with } \\
\text { counseling (exercise, dietary education and } \\
\text { behavior change) by doctors and a nurse for } 24 \\
\text { weeks. }\end{array}$ & $\begin{array}{l}\text { It was found that the mean anthropometric } \\
\text { measurements and the cardiometabolic risk } \\
\text { decreased; medium high density lipoprotein (HDL- } \\
\text { C) cholesterol increased and the prevalence of } \\
\text { metabolic syndrome decreased by } 20.8 \% \text {. }\end{array}$ & 2 \\
\hline $\begin{array}{l}\text { Marild, Gronowitz, Forsell, Dahlgren, Friberg. } 2012^{12} \\
\text { Sweden }\end{array}$ & $\begin{array}{l}\text { Randomized, } \\
\text { multicenter clinical trial. } \\
\mathrm{n}=64 \\
\text { children and adolescents } \\
\text { aged nine to } 13 \text { years } \\
\text { with normal weight and } \\
\text { obesity. }\end{array}$ & $\begin{array}{l}\text { A lifestyle change counseling program was } \\
\text { implemented for } 12 \text { months. In one of the groups, } \\
\text { the physical therapist replaced the nurse in one } \\
\text { third of the sessions to stimulate physical activity. } \\
\text { Normal weight, overweight and obese children } \\
\text { were compared. }\end{array}$ & $\begin{array}{l}\text { It has been shown that, of the } 55 \text { children who } \\
\text { completed treatment, } 13(24 \%) \text { changed from } \\
\text { obese to overweight condition, } 42(76 \%) \text { remained } \\
\text { unchanged with the weight and no increased five } \\
\text { units of baseline BMI. No significant difference was } \\
\text { identified between the groups. }\end{array}$ & 2 \\
\hline $\begin{array}{l}\text { Hessler, Siegrist. } 2012^{13} \\
\text { USA }\end{array}$ & $\begin{array}{l}\text { Exploratory, } \\
\text { descriptive and } \\
\text { correlational. } \\
\mathrm{n}=1,088 \\
\text { nurses working in urban } \\
\text { and rural areas. }\end{array}$ & $\begin{array}{l}\text { Questionnaires were used to investigate nurses' } \\
\text { attitudes towards obesity in children, exploring } \\
\text { their diagnostic and treatment practices. }\end{array}$ & $\begin{array}{l}\text { Nurses recognized obesity as a problem that } \\
\text { requires treatment, but did not evaluate or } \\
\text { diagnose overweight. It was found that, in the } \\
\text { rural region, resources to refer cases of obesity to } \\
\text { other levels of care were scarce. }\end{array}$ & 6 \\
\hline $\begin{array}{l}\text { Yarborough, DeBar, Wu, Pearson, Stevens. } 2012^{14} \\
\text { USA }\end{array}$ & $\begin{array}{l}\text { Randomized controlled } \\
\text { trial. } \\
\mathrm{n}=11 \text { professionals } \\
\text { (eight pediatricians, two } \\
\text { primary care nurses and } \\
\text { one school nurse). }\end{array}$ & $\begin{array}{l}\text { Interviews were conducted with professionals to } \\
\text { identify barriers to the management of obesity in } \\
\text { children and adolescents and to provide training } \\
\text { for a group of professionals who tested it through } \\
\text { lifestyle change counseling. }\end{array}$ & $\begin{array}{l}\text { Difficulties were reported in discussing weight } \\
\text { issues and lack of time. It was found that those } \\
\text { who received training reported greater ease of } \\
\text { working with overweight in adolescents and more } \\
\text { confidence to motivate them to adopt a healthy } \\
\text { lifestyle. }\end{array}$ & 2 \\
\hline $\begin{array}{l}\text { Tucker, Ytterber, Lenoch, Schmit, Mucha, Wooten, et al. } \\
2013^{15} \\
\text { USA }\end{array}$ & $\begin{array}{l}\text { Quasi-experimental, } \\
\text { community intervention. } \\
\mathrm{n}=130 \text { children and } \\
\text { adolescents aged four to } \\
18 \text { years. }\end{array}$ & $\begin{array}{l}\text { Intervention was performed for } 12 \text { months through } \\
\text { a motivational interview conducted by nurses to } \\
\text { reduce overweight compared to standard clinical } \\
\text { care (BMI assessment, weight reduction guidance } \\
\text { and referrals when necessary). }\end{array}$ & $\begin{array}{l}\text { Differences between groups were not found to be } \\
\text { significant for BMI, however, reductions were } \\
\text { greater in the intervention group, which also } \\
\text { increased daily fruit / vegetable intake, physical } \\
\text { activity, and decreased hours watching television. }\end{array}$ & 3 \\
\hline $\begin{array}{l}\text { Riiser, Londal, Ommundsen, Smastuen, Misvaer, Helseth. } \\
2014^{16} \\
\text { Norway }\end{array}$ & $\begin{array}{l}\text { Randomized controlled } \\
\text { clinical trial. } \\
\mathrm{n}=120 \\
\text { teenagers aged } 13 \text { to } 15\end{array}$ & $\begin{array}{l}\text { A } 12 \text {-week online program providing personalized } \\
\text { physical activity counseling based on self- } \\
\text { determination theory and motivational } \\
\text { interviewing was accessed for } 12 \text { weeks. In the } \\
\text { control group, standard follow-up of school nurses }\end{array}$ & $\begin{array}{l}\text { Cardiorespiratory fitness was slightly impacted and } \\
\text { moderately quality of life. There was a } \\
\text { significantly lower increase in BMI in the } \\
\text { intervention group than in the control group. }\end{array}$ & 2 \\
\hline
\end{tabular}


Windham, Hastings, Anding, Hergenroeder, EscobarChaves, Wiemann. 201417

USA

Keating, McCurry. $2015^{18}$

USA

Nelson, Vos, Walsh, O'Brien, Welsh. $2015^{19}$

USA

Pbert, Druker, Barton, Schneider, Olendzki, Gapinski, et al. $2016^{20}$

USA

Tyler, Horner. $2016^{21}$

USA

Panca, Christie, Cole, Costa, Gregson, Holt, et al. $2018^{22}$
Actions of nurses directed at obese teens in... years.

school and in a sport).

clinical trial. $\quad$ assessment and counseling) plus the use of a

\section{$\mathrm{n}=40$}

$\mathrm{n}=40$
overweight and obese obesity-related illnesses; readiness, motivation

ages 12 and self-efficacy to lose weight and connection

Descriptive. Systematic

review.

$\mathrm{n}=7$

studies

involving

adolescents

20 years.

Exploratory,

descriptive.

$\mathrm{n}=656$ professionals

(265 pediatricians, 143

family doctors and 248

nurses).

Randomized clinical trial

controlled.

overweight and

obese

school

adolescents.

clinical

trial.

$\mathrm{n}=60$ children and

adolescents aged

eight and 12 years. with the health service. Standar
provided for the control group. and health centers. weight control in children. well as support for written materials) Conventional care was provided to the control group. $n=126$ overweight and
The motivation to lose weight and the self-efficacy to choose the diet of adolescents in both groups were improved. It was found that the educational and motivational DVD did not change adolescents' weight-related outcomes, but parents who watched the DVD reported improvements in their knowledge of obesity-related illnesses.

Research that used text messaging as an It was found that there was no consensus on which intervention to treat or prevent obesity in content / themes were most useful. It was found adolescents was analyzed. Text messages aimed at that the time and frequency of messages were not weight loss were used in tertiary and community demonstrated and that there was no significant care settings such as secondary schools, colleges relationship between text message and BMI decrease, since the interventions analyzed had other intervention components.

A structured questionnaire was applied to primary Most professionals assessed fruit and vegetable care professionals to evaluate and compare intake (83\%) and physical activity (78\%). Goal perceptions and counseling practices related to setting has been reported to be effective $(88 \%)$ and practitioners are able to encourage change in habits $(85 \%)$, although they are less confident in their ability to counsel $(72 \%)$

The effectiveness of a counseling intervention It was found that the intervention group did not provided by the school nurse and an exercise show significant differences in BMI reduction or program to improve activity, diet and BMI were body fat percentage, but showed improvements in evaluated compared to only individual food intake, such as increase in breakfast consultations with weight counseling nurses. consumption.

The intervention was based on five follow-up visits It was shown that there were no significant by the nurse for weight management focused on changes in BMl percentile between groups, behavior change (diet and physical activity, as however, when this factor was transformed in identified.

Parents in both groups reported improvements in children's eating and activity behaviors and pointed out the difficulties in trying to change their habits, but parents in the intervention group issued more positive responses.

Controlled clinical trial. Lifestyle focused on motivation for change and Costs were found to be significantly higher in the 
Jesus MCP, Braga VAS, Pinheiro APS, et al

England

Busch, Hubka, Lynch, $2018^{23}$

USA

Figure 2. Summary of selected articles. Sao Paulo (SP), Brazil, 2019.
Actions of nurses directed at obese teens in...

self-esteem during 12 sessions over six months. intervention group. It was found that no evidence $\mathrm{n}=174$ obese The control group was provided with a single was found that the intervention was more adolescents between 12 session with conventional weight management effective than a single educational session to and 19 years old. guidelines provided by the nurse. improve the quality of life of young people. $\begin{array}{ll}\text { guidelines provided by the nurse. } & \text { improve the quality of life of young people. } \\ \text { Intervention has been shown to be associated with }\end{array}$ higher costs.

Exploratory, An interview was used to evaluate the Lack of time (73\%) and parental resistance $(77 \%)$ descriptive. interventions, knowledge and limitations in the were shown to be the most frequent barriers, in management of childhood obesity in the context addition to prioritizing other demands, lack of of PHC and perform an educational intervention confidence and specific training for the approach. for these professionals. It was found that educational intervention increased from $6 \%$ to $16 \%$ referrals to other services and laboratory tests, from $14 \%$ to $26 \%$. 


\section{DISCUSSION}

It is known that the prevalence of chronic noncommunicable diseases in adolescence is a concern of health services today and its occurrence is mainly associated with cardiovascular and metabolic diseases, including obesity. ${ }^{24}$ This review included This study showed that laboratory data from obese children and adolescents differed significantly from those of normal weight, especially the dosages of insulin, triglycerides, low and high density lipoproteins and apolipoproteins. These changes represent an important risk factor for the development and aggravation of chronic diseases. ${ }^{12}$

These adolescent health problems tend to be perpetuated during adulthood and impact the morbidity and mortality of this public. ${ }^{25-6}$ In this sense, it is emphasized that the actions developed by nurses aimed at this clientele, with emphasis on the adoption of healthy lifestyle habits, can mitigate health problems.

After intervention based on lifestyle modification guidelines, with emphasis on healthy eating habits and physical activity practice, it was found that the average of all anthropometric measurements and cardiometabolic risk factors of obese children and adolescents between two and 18 years decreased significantly and the average HDL-C had a considerable increase. ${ }^{11}$ It was also identified in a program aimed at changes in the lifestyle of this audience, developed by nurse and multidisciplinary team, which in most participants , there was a reduction in $\mathrm{BMI}$, with changes in the classification of obese overweight. ${ }^{12}$

It was found, from the studies identified in the literature, that the main subjects evaluated and addressed by nurses and other primary care health professionals addressed to obese adolescents were the incentive to adopt healthy lifestyle habits, especially the encouragement of eating. healthy, physical activity practice and self-esteem improvement. ${ }^{11-2,15-17,19-21}$ Among the elements of the approaches to adolescents are the assessment of fruit and vegetable consumption, alcohol use, time spent in front of the screens (television, computer and smartphones) and sports time.

Counseling was based mainly on the following components: change in eating behavior; encouraging better dietary patterns by reducing the intake of energy-rich foods; improving food choices and addressing emotional eating triggers, as well as decreasing sedentary behavior and increasing physical activity time. ${ }^{11-2,15-7,19-21}$ The importance of developing actions involving the family is emphasized in obese adolescents' health, since habits and family dynamics can influence the weight of young people.

It was evident from research conducted in the USA that the approach of the nurse to the family with obese children or adolescents, through home counseling, provided, from the perspective of parents, improvements in their children's behaviors and easier to establish healthy family routines. ${ }^{21}$ In a non-randomized clinical trial based on nurses' advice to improve their lifestyle, it was found that adolescents and their families increased the consumption of fruits, vegetables and hours of physical activity, decreasing hours of television watched. ${ }^{15}$

In research, it was emphasized that long-term interventions had positive and more significant results. ${ }^{15,21}$ It was found in a systematic review that longer-term treatments based on guidance for lifestyle changes aimed at adolescents may lead to better results in weight loss and blood pressure when compared to shorter treatments based only on prescription. ${ }^{3}$

The importance of longitudinal nursing care plans based especially on health education and support for changing lifestyle habits in order to favor weight loss among adolescents is emphasized. It is noteworthy that long-term educational practices may be able to favor the incorporation of healthy habits and positively impact adolescents' quality of life. ${ }^{15}$

It is noticed, in the scope of actions developed in PHC, that the almost inexistence of face-toface contacts between nurses and adolescents can be a hindrance in the health monitoring of this public. The need for changes aimed at increasing the accessibility of young people and adolescents to health services is emphasized. In this sense, it was evidenced that the application of online technologies by school nurses for personalized physical activity counseling was an important tool for adolescents to be sensitized regarding the adoption of healthy lifestyle habits. This study obtained positive results regarding the improvement in cardiorespiratory fitness, weight control and quality of life of these adolescents. ${ }^{16}$

It was also shown in an integrative review included in this study that research that used smartphone text messaging for the prevention or control of obesity in adolescents, despite not having impacted body weight, was considered as an approach with good acceptability, representing a possibility for professionals to get closer to this audience. ${ }^{18}$ It is emphasized that digital technologies were effective in promoting healthy eating. ${ }^{27}$

Research conducted by a multiprofessional team found that the use of educational DVDs helped improve parents 'knowledge of obesityrelated illnesses, although the resource was not able to change families' body weight. ${ }^{17}$

In addition, the advice given by nurses with emphasis on the adoption of a healthy lifestyle can be an important factor in encouraging change, especially when adolescents have risk factors for chronic diseases. ${ }^{22}$ In an integrative literature review, it was identified that the most prevalent 
Jesus MCP, Braga VAS, Pinheiro APS, et al

risk factors for chronic diseases among adolescents are inadequate diet, physical inactivity, alcohol abuse and tobacco use. This review showed the importance of strategies that include such factors to minimize their negative impacts on adolescent health. ${ }^{24}$

It was pointed out in a research conducted in the USA that nurses' actions aimed at adolescents with obesity should not be restricted to the individual level. It has been found that counseling and out-of-school physical exercise, although beneficial for weight reduction, are not sufficient to remedy the problem of obesity in adolescence as it is a complex problem that requires social and environmental change. ${ }^{20}$

It was evidenced, through a systematic review of the literature, that the articulation between the health sector, schools and other social facilities is necessary in facing obesity due to the multifactorial character of this problem. It is known that broad and integrated practices, permanently, may favor users' adherence to health services. ${ }^{28}$ It is emphasized that intersectoral articulation may result in actions that encourage adolescents to adopt a healthy lifestyle, aiming at control and prevention of weight gain.

Mainly, the importance of the articulation between PHC and the school is emphasized, since the primary care services are located near the communities and have professionals able to develop actions that can interfere with the adolescents' lifestyle, contributing to the improvement of their health and citizenship conditions. It is noteworthy that, in addition to schools, these services can work together with community movements, with different groups of young people, including religious, among other places frequented by this public, which favors the creation or strengthening of the bond between adolescents and the health professional. ${ }^{29}$

It is pointed out that the articulation of the health service with the school is essential for the practices to be supported by constructive and horizontal discussions with adolescents and other actors who participate in youth development in order to strengthen a safety net. In the Brazilian context, we highlight the Health at School Program and initiatives aimed at bringing primary health care professionals closer to this social equipment to meet the main demands of adolescents in an integral and longitudinal manner. ${ }^{30}$

In this context, the nurse occupies a fundamental position as a professional in primary care teams, being able to act with adolescents in order to promote positive impacts on their health conditions, as shown in the studies included in this review. Therefore, these professionals are considered to represent a respected source of information and potential to work with this group
Actions of nurses directed at obese teens in...

with obesity, both in the units and in other spaces of the community. ${ }^{31}$

Investigations were identified that showed that health professionals working in PHC had difficulties working with obese adolescents. The most prominent barriers were the lack of specific specialized services for the referral of obese children and adolescents; lack of interest and difficulty for behavior change by adolescents; parental resistance to treatment; poor integration between health services; the lack of guidelines for obesity management 19 the lack of time of professionals; little confidence in providing weight reduction counseling and the need for investment in professional training. ${ }^{14,19,23}$

It was noticed that the difficulties registered in the context of health services involve both users and the organization of primary care units and may negatively impact the management of obesity in adolescents, worsening their conditions. It was found in a study conducted in the USA that although nurses considered it necessary to treat obesity, nurses could not evaluate or diagnose overweight according to current guidelines; and in rural areas there were few resources to refer cases of juvenile obesity to other levels of care, which prevented the continuity of follow-up. ${ }^{13}$

Based on the acknowledgment of these limitations, the need for reorganization of health services, as well as training of professionals who work in them, which pointed to improvements in the identification and monitoring of cases of obesity in adolescents, was pointed out. In an investigation, it was evidenced that in-service training to equip health professionals for the management of obesity with adolescents was able to generate easier for them to work with adolescents and increased professional confidence to motivate adolescents to perform healthy lifestyle changes. ${ }^{14}$

It was noted that the training of primary care health professionals was also efficient to increase the referral rate of obese children and adolescents to the referral services existing in the Health Care Network and the provision of necessary laboratory tests for this public. ${ }^{23}$

It is noteworthy that, in the search carried out, national studies on the performance of nurses alone or in a multidisciplinary team in PHC aimed at adolescents with obesity did not emerge, which highlights the importance of developing studies on this subject in the Brazilian health context.

It can be seen that the findings gathered in this review may contribute to the increase of knowledge in the area of adolescent health and enable nurses to reflect on the relevance of performing interventions aimed at this public with obesity in PHC, aiming at health promotion and prevention of health problems in adolescence. 


\section{CONCLUSIN}

It was found that the scientific production on the actions of nurses aimed at obese adolescents in PHC included mostly intervention studies conducted in countries of the European and American continents, especially in the USA, in primary care units and in the school environment, as well as descriptive studies about the perception of health professionals about their actions with this public.

It was evidenced that the nurses' actions were based on counseling, the use of technologies and the involvement of the family of obese children and adolescents, to promote a healthy lifestyle by stimulating healthy eating, physical activity and improving self-esteem for weight reduction.

The need for the development of longitudinal, intersectoral and broad actions is pointed out, as well as greater investment in the training of nurses, with reference to integral care.

$\begin{array}{llll}\text { FIUNDING } & & \\ \text { National Council for Scientific and }\end{array}$

Technological Development (CNPq) - Brazil. Financing Code 3032449 / 2017_5.

\section{REFERENCES}

1. World Health Organization. Obesity [Internet]. Geneva: WHO;2019 [cited 2018 Dec 20]. Available from: http://www.who.int/topics/obesity/en/

2. Bloch KV, Klein $\mathrm{CH}$, Szklo M, Kuschnir MCC, Abreu GA, Barufaldi LA, et al. ERICA: prevalences of hypertension and obesity in Brazilian adolescents. Rev Saúde Pública. 2016;50(1):9. DOI: http://dx.doi.org/10.1590/s01518-

\subsection{5}

3. O'Connor EA, Evans CV, Burda BU, Walsh ES, Eder M, Lozano P. Screening for obesity and intervention for weight management in children and adolescents: evidence report and systematic review for the US preventive services task force. JAMA. 2017 June;317(23):2427-44. DOI: 10.1001/jama.2017.0332

4. Quek YH, Tam WWS, Zhang MWB, Ho RCM. Exploring the association between childhood and adolescent obesity and depression: a metaanalysis. Obes Rev. 2017 July;18(7):742-54. DOI: 10.1111/obr. 12535

5. Ministério da Saúde (BR), Secretaria de Atenção à Saúde, Departamento de Ações Programáticas e Estratégicas. Proteger e cuidar da saúde de adolescentes na atenção básica [Internet]. Brasília: Ministério da Saúde;2017 [cited 2018 July 15]. Available from: http: / /bvsms.saude.gov.br/bvs/publicacoes/prote ger_cuidar_adolescentes_atencao_basica.pdf

6. Dillen SM, Noordman J, Dulmen S, Hiddink GJ. Examining the content of weight, nutrition and physical activity advices provided by dutch practice nurses in primary care: analysis of videotaped consultations. Eur J Clin Nutr. 2014 Jan;68(1):50-6. DOI: 10.1038/ejcn.2013.219

7. Soares CB, Hoga LAK, Peduzzi M, Yonekura T, Silva DRAD. Integrative review: concepts and methods used in nursing. Rev Esc Enferm USP. 2014 Apr;48(2):329-39.

DOI:

http://dx.doi.org/10.1590/S00806234201400002000020

8. Milner KA, Cosme S. The PICO game: an innovative strategy for teaching step 1 in evidence-based practice. Worldviews Evid Based $\begin{array}{lll}\text { Nur. } & 2017 \quad \text { Dec;14(6):514-16. DOI: }\end{array}$ 10.1111/wvn.12255

9. World Health Organization, Department of Child and Adolescent Health and Development. Adolescent job aid: a hand desk reference tool for primary level health workers [Internet]. Geneva: WHO;2010 [cited 2019 Apr 14]. Available from: http://www.searo.who.int/entity/child_adolescen t/documents/Publications_Adolescent_Job_Aid1.p df?ua=1

10. Galvão CM. Evidence hierarchies. Acta Paul Enferm. $2006 \quad$ Apr/June;19(2):5. DOI: http://dx.doi.org/10.1590/S0103-

\section{1}

11. Kelishadi R, Malekahmadi $M$, Hashemipour $M$, Soghrati $M$, Soghrati $M$, Mirmoghtadaee $P$, et al. Can a trial of motivational lifestyle counseling be effective for controlling childhood obesity and the associated cardiometabolic risk factors? Pediatr Neonatol. $2012 \quad$ Apr;53(2):90-7. DOI: 10.1016/j.pedneo.2012.01.005

12. Marild S, Gronowitz E, Forsell C, Dahlgren J, Friberg P. A controlled study of lifestyle treatment in primary care for children with obesity. Pediatr Obes. 2013 June;8(3):207-17. DOI: 10.1111/j.2047-6310.2012.00105.x

13. Hessler K, Siegrist M. Nurse practitioner attitudes and treatment practices for childhood overweight: how do rural and urban practitioners differ? J Am Acad Nurse Pract. 2012 Feb;24(2):97106. DOI: $10.1111 / \mathrm{j} .1745-7599.2011 .00673 . \mathrm{x}$

14. Yarborough BJ, DeBar LL, Wu P, Pearson J, Stevens VJ. Responding to pediatric providers' perceived barriers to adolescent weight management. Clin Pediatr. 2012 Nov;51(11):106370.

DOI:

https: / /dx.doi.org/10.1177\%2F0009922812459269

15. Tucker SJ, Ytterber KL, Lenoch LM, Schmit TL, Mucha DI, Wooten JA, et al. Reducing pediatric overweight: nurse-delivered motivational interviewing in primary care. J Pediatr Nurs. 2013 Nov-Dec;28(6):536-47.

DOI:

10.1016/j.pedn.2013.02.031

16. Riiser K, Londal K, Ommundsen Y, Smastuen MC, Misvaer N, Helseth S. The outcomes of a 12 week internet intervention aimed at improving fitness and health-related quality of life in overweight adolescents: the Young \& Active 
Jesus MCP, Braga VAS, Pinheiro APS, et al

controlled trial. PLoS One. 2014 Dec;9(12): e114732. DOI: 10.1371/journal.pone.0114732

17. Windham ME, Hastings ES, Anding R, Hergenroeder AC, Escobar-Chaves SL, Wiemann CM. "Teens Talk Healthy Weight": the impact of a motivational digital video disc on parental knowledge of obesity-related diseases in an adolescent clinic. J Acad Nutr Diet. 2014 Oct;114(10):1611-8.

DOI:

10.1016/j.jand.2014.04.014

18. Keating SR, McCurry MK. Systematic review of text messaging as an intervention for adolescent obesity. J Am Assoc Nurse Pract. 2015 Dec;27(12):714-20. DOI: 10.1002/2327-6924.12264 19. Nelson JM, Vos MB, Walsh SM, O'Brien LA, Welsh JA. Weight management-related assessment and counseling by primary care providers in an area of high childhood obesity prevalence: current practices and areas of opportunity. Child Obes. 2015 Apr;11(2):194-201. DOI: 10.1089/chi.2014.0052

20. Pbert L, Druker S, Barton B, Schneider KL, Olendzki B, Gapinski MA, et al. A school-based program for overweight and obese adolescents: a randomized controlled trial. J Sch Health. 2016 Oct;86(10):699-708. DOI: 10.1111 /josh.12428

21. Tyler DO, Horner SD. A primary care intervention to improve weight in obese children: a feasibility study. J Am Acad Nurse Pract. 2016 July/Jan;28:98-106. DOI: $\quad$ 10.1002/23276924.12246

22. Panca M, Christie D, Cole TJ, Costa S, Gregson $\mathrm{J}$, Holt R, et al. Cost-effectiveness of a community delivered multicomponent intervention compared with enhanced standard care of obese adolescents: cost-utility analysis alongside a randomized controlled trial (the HELP trial). BMJ Open. 2018 Feb;8(2):e018640. DOI: 10.1136/bmjopen-2017-018640

23. Busch AM, Hubka A, Lynch BA. Primary Care provider knowledge and practice patterns regarding childhood obesity. J Pediatr Health Care. 2018 Nov/Dec;32(6):557-63. DOI: 10.1016/j.pedhc.2018.04.02

24. Bezerra MRE, Lyra MJ, Santos MAM, Colares V, Menezes VA. Modifiable risk factors for noncommunicable chronic diseases in adolescents: integrative review. Adolesc Saúde [Internet]. 2018 Apr/June [cited 2019 Apr 14];15(2):113-20. Available from: http://www.adolescenciaesaude.com/detalhe_arti go. asp?id=726\&idioma=English

25. Simmonds M, Burch J, Llewellyn A, Griffiths C, Yang $\mathrm{H}$, Owen $\mathrm{C}$, et al. The use of measures of obesity in childhood for predicting obesity and the development of obesity-related diseases in adulthood: a systematic review and meta-analysis. Health Tec Asses [Internet]. 2015 June [cited 2019 Apr 14];19(43). Available from: https://www.ncbi.nlm.nih.gov/books/NBK299575/
Actions of nurses directed at obese teens in...

26. Castro Júnior AR, Abreu LDP, Lima LL, Araújo AF, Torres RAM, Silva MRF. Nursing consultation in the outpatient care of youths. J Nurs UFPE on line. 2019 Apr;13(4):1157-66.

DOI:https: / / doi.org/10.5205/1981-8963v13i04a239115p1157-1166-2019

27. Alcântara CM, Silva ANS, Pinheiro PNC, Queiroz MVO. Digital technologies for promotion of healthy eating habits in teenagers. Rev Bras Enferm. $2019 \quad \mathrm{Mar} / \mathrm{Apr}$;72(2):513-20.DOI: http://dx.doi.org/10.1590/0034-7167-2018-0352

28. Rech DC, Borfe L, Emmanouilidis A, Garcia EL, Krug SBF. Public policies and coping of obesity in Brazil: a reflective review. Rev Epidemiol Control Infec [Internet]. 2016 Aug/Sept [cited 2019 Apr 14];1(1):01-10. Available from: https://online.unisc.br/seer/index.php/epidemiol ogia/article/download/7974/5165

29. Farre AGMC, Pinheiro PNC, Vieira NFC, Gubert FA, Alves MDS, Monteiro EMLM. Adolescent health promotion based on community-centered arts education. Rev Bras Enferm. 2018 Jan/Feb;71(1):26-33. DOI: http://dx.doi.org/10.1590/0034-7167-2016-0078

30. Sousa MC, Esperidião MA, Medina MG. Intersectorality in the 'Health in Schools' Program: an evaluation of the political-management process and working practices. Ciênc saúde colet. 2017 June;22(6):1781-90.

DOI:

http://dx.doi.org/10.1590/1413-

\subsection{6}

31. Banfield M, McGorm K, Sargent G. Health promotion in schools: a multi-method evaluation of Australian School Youth Health Nurse Program. BMC Nursing. 2015 Apr;14:21. DOI: 10.1186/s12912-015-0071-0

\section{Corresponding author}

Vanessa Augusta Souza Braga

Email: vanessabraga@usp.br

Submission: 2019/05/06

Accepted: 2019/08/27

Copyright $\odot 2019$ Journal of Nursing UFPE on line/JNOUL.

(cc) $\mathrm{EY}$ This is an Open Access article distributed under the terms of the Creative Commons AttributionShareAlike 4.0 International License. This license lets others distribute, remix, tweak, and build upon your work, even commercially, as long as they credit you for the original creation. Recommended for maximum dissemination and use of licensed materials. 